Combining a psychological intervention with physiotherapy. A systematic review to determine the effect on physical function and quality of life for adults with chronic pain.

S. Wilson*a and F. Cramp ${ }^{\mathrm{b}}$

${ }^{a}$ Bath Centre for Pain Services, Royal United Hospitals Bath NHS Foundation Trust, Bath, UK; ${ }^{b}$ Faculty of Health and Applied Sciences, University of the West of England, Bristol, UK

Bath Centre for Pain Services, Royal United Hospitals Bath NHS Foundation Trust, Bath, BA1 1RL, UK email: sarah.wilson65@nhs.net 


\section{Combining a psychological intervention with physiotherapy. A systematic review to determine the effect on physical function and quality of life for adults with chronic pain.}

Background

Chronic pain affects approximately 28 million people in the UK. It does not always respond to conventional curative treatments and can have a devastating impact on an individual's ability to function and perform life roles in the way they would like. Psychological approaches to pain management have been advocated for over 40 years, but it is unclear whether the addition of such approaches to physiotherapy increases treatment effectiveness.

Objectives

To systematically review the literature to determine whether the addition of psychological approaches to physiotherapy is more effective in improving physical functioning and quality of life than physiotherapy alone.

Methods

An electronic database search focused on randomised controlled trials comparing a physiotherapy intervention for chronic pain with a matched intervention with an additional psychological therapy component.

All eligible studies were independently reviewed by two researchers and the strength of evidence and results evaluated. A meta-analysis was conducted on post-test mean data for physical functioning.

Results

Eight studies were identified for inclusion. Meta-analysis of the data showed combined treatments to be superior in modifying functional outcomes (standardised mean difference $-1.1295 \%$ confidence intervals -1.94 to -0.31 ). This was echoed in the narrative review of the quality of life evidence. Study quality was variable and thus the findings should be interpreted with caution.

\section{Conclusions}

There is evidence that combining physiotherapy and psychological approaches improves physical function in chronic pain in comparison to physiotherapy alone. Further examination of this field is required to inform changes in practice and to develop treatment methods.

Keywords: Psychological approaches; Physiotherapy; Chronic pain; Physical function; Quality of life 


\section{Background}

Chronic pain is a widespread problem within healthcare with a reported 28 million people in the UK experiencing chronic pain condition of moderate to severe severity [1]. It is disabling and impacts on psychological functioning [1]. Pain is the second most common reason for claiming incapacity benefit with an annual cost of $£ 3.8$ billion; healthcare costs are unknown but general practitioner (GP) appointments for chronic pain have been estimated at $£ 69$ million per year [2]. The complex interaction between physical and emotional suffering makes management of chronic pain a challenge for the 21 st century. Curative treatments can be ineffective, and when combined with unrealistic patient expectations this can lead to unhelpful patterns of investigation and treatment seeking, even where these efforts fail to reduce pain [3]. Chronic pain is a significant financial burden on health and social support systems and profoundly affects the lives of those living with it.

Physical rehabilitation strategies targeted at increasing functioning through exercise and/or manual therapy are common within physiotherapy for chronic pain. A recent review identified some evidence to support multidisciplinary treatments, education and exercise therapy but highlighted the need for further research [4].

Psychological approaches to pain management have been advocated for over 40 years [5] and the role of supporting patients with cognitive and emotional barriers to making changes in the presence of chronic pain is now common practice at a worldwide level. In the UK, pain clinics have adopted these approaches based on the best available evidence and national guidance is available to support this implementation [6]. The limited capacity of these specialised clinics mean that many patients fall between pain management services and more easily accessible outpatient physiotherapy services.

The experience of chronic pain is complex without simple linear relationships between tissue damage, the pain experience, and impact of pain and over the past 15 years physiotherapists have started to acknowledge the broader psychosocial impact of pain [7]. Cognitive behavioural approaches have been adopted within physiotherapy, particularly with a focus on the reduction of chronicity. The BeST trial and STarT Back trial provide examples of interventions combining physiotherapy and psychology which have been demonstrated to be effective in reducing chronicity in low back pain with longer lasting effects than physical treatment modalities alone $[8,9]$.

A 2015 Cochrane review and meta-analysis concluded that multidisciplinary approaches are superior to physiotherapy alone for low back pain. The cost of these approaches however lead to a suggestion that they should be reserved for the most complex cases [10]. In a further review of physical and behavioural treatments for non-specific spinal pain small benefits were reported for pain and disability with no significant difference between interventions. No specific comparisons were made to explore the effectiveness of physiotherapy versus comparable physiotherapy in combination with another treatment [11]. 
Current understanding of psychologically informed physiotherapy approaches has been limited to low back pain with a specific focus on prevention of chronicity. There is however a much broader population of patients experiencing chronic pain and its debilitating impact. Both psychological and multidisciplinary approaches to chronic pain have been studied in some depth and appear both clinically and cost effective [12]. The large number of patients struggling with chronic pain cannot be managed in existing psychology and multidisciplinary pain management programmes hence alternative practical, cost-effective solutions are required. The enhancement of existing physiotherapy practice may be one possible solution to meet the needs of patients with chronic pain.

The aim of this systematic literature review was to evaluate the evidence regarding the addition of psychological treatment approaches to physiotherapy practice for patients with chronic pain. The specific focus was to determine the evidence for the impact of the addition of these approaches on physical function and quality of life. Pain was not selected as an outcome measure due to the lack of reliable link between reported pain levels and physical function [13].

\section{Method}

The review protocol was registered on PROSPERO (CRD42015026434) and conducted according to the preferred reporting items for systematic reviews and meta-analyses (PRISMA) guidelines [14]. Articles were identified using an electronic search of Psychinfo, EMBASE, MEDLINE, Allied and Complementary Medicine Database (AMED) and Web of Science combined with hand searching of review paper reference lists. The search was updated on 14th September 2017. The search strategy, developed with a librarian, is included in figure 1.

Figure 1 here

Both authors independently screened the titles, abstracts and full texts of the total search yield to identify potentially eligible articles in a staged process. The abstracts and then full texts were retrieved where either reviewer considered a citation potentially met the inclusion criteria. Inclusion criteria were that the trial was published in English, randomised and included a control arm, participants were adult patients with a minimum three-month history of non-malignant pain, the study described a physiotherapy intervention arm with a clear theoretical approach and an intervention arm combining an equivalent physiotherapy intervention with a theory driven psychological intervention and measured physical functioning using a standardised measure. Exclusion criteria were the inclusion of patients with recent surgery or with inflammatory, degenerative or life limiting conditions.

Limiting the review to randomised controlled trials (RCT) with comparable physiotherapy interventions eliminated the risk of differences in the physiotherapy component of treatment 
influencing the study results. This allowed the impact of the additional psychology treatment to be independently assessed. The exclusion of degenerative and inflammatory conditions eliminated risk of outcomes being impacted by changes in a progressing underlying condition.

Both authors independently reviewed the full texts which met the inclusion criteria and used a piloted data extraction form to collect information including: publication details, study design, participants, exclusion criteria, overarching physiotherapy and psychological theories, interventions delivered, primary and secondary outcome measures, randomisation procedures, blinding, results, unreported data and adverse events. Disagreements were resolved through discussion. Study authors were contacted where further information was required to determine inclusion and Cochrane Risk of Bias assessments were completed for all included studies [15]. The outcome of the risk of bias assessment is included in table 1. The Scottish Intercollegiate Guidelines Network (SIGN) methodology checklist 2 for randomised controlled trials was used for each study to inform the narrative review [16]. Evidence tables were produced to summarize the studies.

If the data were available, and it was appropriate to do so, it was proposed that the studies would be combined in a meta-analysis. We proposed to calculate the mean difference in physical function between the intervention (physiotherapy plus psychological approach) and control (physiotherapy only) arms. If heterogeneity between studies was suspected, for example where outcome measures vary between studies, the possibility of utilising a random effects model of meta-analysis would be considered.

\section{Results}

The electronic database search yielded 1060 citations. Thirteen articles were included in the final analysis which reported the findings of eight studies. A flow diagram of the review process is included in figure 2. A narrative review of the studies is included below along with a meta-analysis for physical functioning using post-test means. Table 1 summarises the included studies and table 3 summarises the study results.

Figure 2 here

Table 1 here

\section{Participants}


All studies recruited patients with spinal pain which persisted three months following onset. Four studies included patients with low back pain [17,21,22,26] and four included patients with neck pain $[18,20,23,28]$. No information was provided in any of the studies about previous physiotherapy or psychology treatment input for the pain conditions. Only one study reported a significant difference between arms for age [23] with those in the combined treatment arm being older.

\section{Interventions and training}

The interventions included in the studies are detailed in table 2. Physiotherapy varied from a general exercise protocol including strengthening and cardiovascular exercise $[17,26,18,20]$, manual therapy in combination with exercises for strengthening and postural control [21$23,28]$. Psychological interventions were all based upon a cognitive behavioural model. Of the eight studies six described the model used as Cognitive Behavioural Therapy $[17,21,22,26,20,23]$ one as a Functional Behavioural Analysis approach [28]and one as an operant behavioural approach [18]. There was overlap in the CBT methods with graded activity and problem solving being used in two studies [17,26], graded activity and modification of thoughts and pain behaviours being used in four studies [21,22,20,23].

All treatments were delivered by physiotherapists in four studies [17,18,23,28], other studies used clinical psychologists $[21,22,20]$ or clinical psychologists and social workers [26]. It was difficult to determine the equivalence of training and experience across the studies; Smeets [26] described an extensive training package and provided a detailed account of the treatment delivered whereas Monticone [23] described the treating physiotherapists as having over 20 years' experience in delivering manual therapy, but the level of training in CBT was acknowledged to be low. One study reported the physiotherapist to be experienced but again gave no detail of their training in psychological approaches [18]. One study described the physiotherapists delivering the combined treatment receiving supervision from a clinical psychologist [23]. Two studies described the combined treatment being delivered by a multidisciplinary team of a doctor, psychologist, occupational therapist and physiotherapist $[21,22]$. Only one study measured treatment integrity, however the results were not included in the publication [28]. Smeets [26] reported that there were no statistically significant protocol deviations between arms and provided a level of detail which would be adequate for the trial to be reproduced. The lack of detailed protocols and details of training makes it impossible to determine the quality of these interventions.

\section{Withdrawal from study and adverse events}

Rates of adverse effects were generally low across the studies. Smeets [26] reported six adverse events (2.64\%) due to increased pain during the treatment phase and Monticone [20] 
reported transient pain worsening and mood disorders in a total of 33 patients (19.41\%) with neither study showing a difference between study arms. Details of these adverse events are included in table 1. Six studies did not report on adverse events so it is unclear whether these may have occurred [17,21-23,28] although some of the withdrawals reported by Ludvigsson [18] included increased pain indicating there may have been further unreported adverse events. Fifteen patients $(6.61 \%)$ did not complete adequate treatment due to treatment rejection (four in the active physiotherapy arms and 11 in the combined treatment arm) in the study by Smeets [26]. Monticone [23] reported five dropouts in the physiotherapy only condition and Soderlund and Lindberg [28] reported one patient in the combined treatment who did not comply with treatment. The highest withdrawal rates were reported by Ludvigsson [18] with $11.27 \%$ in the combined physiotherapy and psychology arm and $23.68 \%$ in the physiotherapy only arm. With nearly a quarter of patients withdrawing between pre and post treatment questions are raised about acceptability.

\section{Methodological quality}

Table 2 summarises the Cochrane Risk of Bias findings for the eight studies included in the final analysis. Key weaknesses were the high risk of performance bias across all studies as it was not possible to blind participants to treatment. Risk of selection bias was also unclear for two studies due to inadequate description of concealment procedures [17,28].

Detection bias was affected by a lack of blinding in one study [28]. Two further studies did not report on blinding $[17,26]$. Attrition bias was high for one study due to the outcomes of a participant who did not comply with treatment being excluded [28]. A further four studies had participants withdraw, Smeets [26] performed an intention to treat analysis with baseline outcomes carried forward which minimised the risk of this affecting the findings. Three studies reported using an intention to treat analysis, however the methods for this were not reported $[17,20,23]$.

One study did not report on treatment integrity, despite this being included in the method, putting it at high risk of reporting bias [26]. Risk of other biases included the lack of treatment fidelity testing across all studies aside from Smeets [26]. One study also offered acupuncture and heat based pain relieving modalities in the physiotherapy only arm, these were not measured and therefore their impact on the outcomes cannot be determined [28]

The small sample sizes in three of the studies makes it difficult to assess whether the findings are reliable or generalizable $[17,21,28]$.

Table 2 here 


\section{Effect of treatment on quality of life}

Quality of life was measured in four studies, each of these used the Short-Form Health Survey Questionnaire (SF36). Monticone [23] demonstrated non-significant difference in favour of the combined treatment whilst Monticone $[21,22,20]$ showed statistically significant effects of time, group and time-by group interaction in favour of the combined physiotherapy and psychology treatment. Meta-analysis was not carried out on these data as only subscale scores for the physical and mental components of the SF36 were available.

\section{Effect of treatment on physical function}

Physical function was measured in all eight studies. Three studies showed statistically significant between group differences in favour of the combined treatment $[21,22,20]$ and four $[17,26,18,23]$ showed statistically significant differences from pre to post treatment with no significant difference between groups. Soderlund and Lindberg [28] did not demonstrate statistically significant changes in either group between pre and post treatment.

Table 3 here

\section{Meta-analysis}

Seven of the eight studies were included in the meta-analysis for physical function. The individual study results are presented in table 3. Smeets [26] were contacted for their post-test means which were not included in their publication, however these data were not provided. Data were pooled using a random effects model due to heterogeneity. Meta-analysis revealed a large effect size in favour of the physiotherapy combined with psychological approach (standardised mean difference: -1.12 : $95 \%$ confidence intervals: -1.94 to $0.31, \mathrm{p}=0.007$ ). The full results are presented in figure 3 below.

Figure 3 here

\section{Discussion}

Eight studies were identified which compared physiotherapy only treatment with physiotherapy treatment plus a psychological intervention for chronic pain. These studies covered spinal pain, but none were found that included patients with localised pain away from the spine, widespread pain conditions, headache, or visceral pain. This may be due to 
issues of heterogeneity around diagnosis of non-spinal pain conditions, spinal pain patients may also be more easily recruited from orthopaedic and musculoskeletal caseloads. There was a pattern of increase in number and quality of studies and reduction in risk of bias over time, however based on such a small number of studies it is difficult to infer whether this may be a pattern that will continue, particularly as $50 \%$ of the studies came from the same research group.

The treatments delivered in the physiotherapy arms varied including manual therapies, heat and acupuncture, as well as exercise therapies. These combined treatment approaches reflect the range of treatments applied in current physiotherapy practice for spinal pain conditions, however these modalities themselves do not have a strong evidence base [4]. Whilst it is difficult to extrapolate the potent elements of treatment the use of a control and intervention arm allows physiotherapy only treatment to be compared with physiotherapy treatment with an added component of psychological therapy. Further work is required to investigate which physiotherapy interventions are most effective for chronic pain conditions and cease delivery of treatments that are not found to be clinically and cost effective. For example both acupuncture and Transcutaneous Electrical Nerve Stimulation were not recommended for low back pain or sciatica in the most recent guidelines from the National Institute for Health and Care Excellence due to an absence of persuasive evidence [30].

Meta-analysis showed that combined physiotherapy and psychology treatment was statistically significantly superior in improving physical functioning over physiotherapy alone. Three of the four most recent studies indicate that the addition of a psychological intervention to physiotherapy resulted in better outcomes in physical functioning and quality of life, however in all of these studies the psychology component was delivered by clinical psychologists $[21,22,20]$. It is of note that one of these studies included an extensive year long period of intermittent treatment [22]. This appeared to be effective, however in the current healthcare climate of the United Kingdom it is unlikely that this approach would be feasible. The study sample sizes were small overall with between 10 and 85 participants in each arm. Six of the studies included power calculations and matched these with their recruitment [17,22,26,18,20,23]. Monticone [21] was only a small pilot study. Pilot studies are designed to test procedures of a larger RCT such as recruitment retention, appropriateness of measures and proof of concept and the results of this study in isolation should be interpreted with caution [31].

The three studies which showed an enhancing effect of the addition of a psychological approach to physiotherapy used experienced psychologists to deliver the psychological component of treatment $[21,22,20]$. The skill levels of psychologists to deliver psychological therapy is higher than physiotherapists due to their specificity in training and this may have impacted on the results. It is possible that where the addition of psychological approaches did not enhance treatment this may have been due to the skill level associated with the treatment delivery. Excluding studies which used healthcare professionals other than physiotherapists may have provided a clearer picture of the treatment outcomes achievable by psychologically 
enhanced physiotherapy input. It is conceivable that attention to training needs of physiotherapists may enable them to deliver effective psychologically enhanced treatments.

Two studies were low quality $[21,28]$. One of these showed no statistically significant effect over time of either physiotherapy or combined physiotherapy and psychology interventions on physical functioning [28]. The other showed a statistically significant increase in physical functioning and quality of life for both groups over time with a combined physiotherapy and psychology treatment showing a statistically significantly greater effect [21]. The extension of the pilot study by Monticone [21] to a full RCT would provide more robust outcomes.

Six studies were of moderate quality [17,22,26,18,20,23]. Four showed significant improvements in physical functioning in both physiotherapy and combined treatment arms over time but no significant difference between arms [17,26,18,23]. Monticone [23] also showed quality of life to significantly improve over time but not between arms. Two moderate quality studies demonstrated statistically significant improvements in both physical functioning and quality of life with significant time-by-group differences in favour of the combined treatment, both studies employed highly intensive treatment which may not be cost effective or practical to implement $[22,20]$.

\section{Implications for practice}

The addition of psychological approaches to physiotherapy interventions may provide some additional benefit, however these benefits must also be considered in the context of the cost of treatment enhancement. Health economic data is not available for the treatments included in this review, however the increased treatment time involved in the majority of studies indicated that treatment delivery costs could increase as well as there being training cost implications. These would need to be balanced by cost savings in areas such as medical consultations, medication use or unemployment costs to demonstrate value. Further work to distil the potent clinical methods may assist in the translation of highly intensive research treatment protocols to viable clinical protocols for care.

To ensure that psychological interventions could be implemented in physiotherapy settings a clear model for treatment is required and issues around training and treatment fidelity need to be addressed. A recent review of the behaviour change theories and techniques in physiotherapist led pain self-management programmes uncovered substantial problems, including inconsistency in theory implementation [32]. Further problems in implementation emerge in another recent review of physiotherapist's perceptions of practice which suggested that although physiotherapists are aware that psychological approaches may be beneficial, they do not feel competent to deliver them [33]. Concerningly a review by Synnott suggests that as well as not feeling prepared to treat chronic pain following under and post graduate training, that physiotherapists may only partially recognise the cognitive, emotional and social factors impacting in chronic pain and express a preference for biomedical treatments regarding complex factors as out of their scope of practice [34]. We are yet to fully understand whether training packages can address both therapist attitudes and perceptions of their skill levels and so change therapist behaviour resulting in improved patient outcomes. 
Recent reviews of the effectiveness of group self-management programmes for low back pain which included a wide range of physiotherapy only and multi-disciplinary programmes concluded that such interventions are as effective as individual physiotherapy or medical management, however limitations reported in the studies included too much focus on pain scores perhaps resulting in inadequate assessment of behaviour change [35]. Treatment fidelity has also been described as poor, although it is unclear whether this is due to lack of consistency between delivery and prescribed models or limited reporting of fidelity checks in published research [36]. This review highlights three areas for development in clinical practice; 1) clear definitions of the content of physiotherapy based self-management programmes; 2) determining acceptability of these programmes to physiotherapists and 3) training of physiotherapists in the effective delivery of the programmes.

\section{Implications for research}

As indicated above the clinically potent methods within both physiotherapy and psychology models are not apparent from the available research. Further work to extrapolate the important elements of treatment for spinal and other chronic pains is required, alongside the testing of brief interventions based upon the potent clinical components identified. Multicentre trials are also required to reduce the risk of type one error due to localised populations or treatment environments where findings may not generalise to broader clinical populations.

The small number of studies identified ranging over a 16-year period reflects a lack of research focused on the implementation of biopsychosocial treatments in physiotherapy for chronic pain. This mirrors a clinical environment where patients often transition from unidisciplinary primary care settings into specialised pain services where self-management programmes or psychologically based pain management programmes dominate practice. There are many studies of psychological treatments for chronic pain which include pain management programmes. These are summarised in Cochrane reviews [10,37]. The addition of psychological approaches to physiotherapy has not however been thoroughly studied. This may be due to a slow transition in practice which has not been tested using robust research methods. To ensure effective patient care further research in this field is required.

In terms of methodological quality, the design and treatment fidelity of the interventions requires greater attention. This is a longstanding challenge for a profession with treatment approaches as diverse as physiotherapy. The addition of methods traditionally seen as outside the scope of physiotherapy practice raises professional issues of competence and supervision on top of questions of efficacy.

The introduction of pain education and motivational interviewing approaches into physiotherapy highlights a change in clinical practice. Future research will need to determine how these approaches compare with more traditional physiotherapy approaches and psychological interventions combined with physiotherapy. When treatments are combined it 
is possible that an interaction effect occurs. This was beyond the scope of this review; however further study of the impact of physiotherapy and psychological approaches being delivered separately or in combination may assist in understanding the mechanisms which influence this.

\section{Limitations}

The strength of evidence provided by this review is constrained by quality and volume of the available studies. The review question was narrow to ensure relevance of the findings, however a broader review of biopsychosocial approaches used in chronic pain may enhance understanding of the treatment approaches utilised and their impact on function. Long-term follow-up of outcomes was insufficient to enable a meta-analysis leaving questions about the lasting effects of treatments.

Pain intensity was not scrutinised as a part of this review which focused on patient functioning. Whilst clinically and socially patient functioning appear important, the outcomes desired by patients may differ and pain intensity may be an important variable in determining treatment efficacy. Repetition of this review with pain as the primary outcome may add to the understanding of patient reported outcomes and the interaction between pain levels and physical functioning.

\section{Conclusion}

Overall there is evidence that combined physiotherapy and psychology interventions to enhance physical functioning are superior to physiotherapy alone for patients with chronic spinal pain. Combined interventions may also lead to greater improvements in quality of life in the presence of chronic spinal pain. Resulting clinical changes remain to be weighed against a potential increase in cost of treatment. Further work is indicated to enhance understanding of both treatment efficacy and the health and social economics involved in these treatment approaches.

\section{Conflicts of interest}

No conflicts of interest. 


\section{References}

[1] Fayaz A, Croft P, Langford RM, et al. Prevalence of chronic pain in the UK : a systematic review and meta-analysis of population studies. BMJ Open. 2016 [cited April 2018]. DOI: 10.1136/bmjopen-2015-010364

[2] Phillips CJ. The Cost and Burden of Chronic Pain. Br. J. Pain. 2009;3:2-5.

[3] McCracken LM. Learning to live with the pain: Acceptance of pain predicts adjustment in persons with chronic pain. Pain. 1998;74:21-27.

[4] Van Middelkoop M, Rubinstein SM, Kuijpers T, et al. A systematic review on the effectiveness of physical and rehabilitation interventions for chronic non-specific low back pain. Eur. Spine J. 2011;20:19-39.

[5] Gatchel RJ, Peng YB, Peters ML, et al. The biopsychosocial approach to chronic pain: Scientific advances and future directions. Psychol. Bull. 2007;133:581-624.

[6] The British Pain Society. The British Pain Society Guidelines for Pain Management Programmes for adults [Internet]. London; 2013. Available from:

https://www.britishpainsociety.org/static/uploads/resources/files/pmp2013_main_FINAL_v6. pdf.

[7] Gifford L. Topical Issues in Pain 2: Biopsychosocial assessment and management Relationships and pain. Gifford L, editor. CNS Press; 2000.

[8] Hill JC, Whitehurst DGT, Lewis M, et al. Comparison of stratified primary care management for low back pain with current best practice (STarT Back): a randomised controlled trial. Lancet 2011;378:1560-1571.

[9] Lamb SE, Lall R, Hansen Z, et al. A multicentred randomised controlled trial of a primary care-based cognitive behavioural programme for low back pain. The Back Skills Training (BeST) trial. Health Technol. Assess. [Internet]. 2010 [cited March 2016]. DOI: $10.3310 /$ hta14410

[10] Kamper SJ. Multidisciplinary biopsychosocial rehabilitation for chronic low back pain : Cochrane systematic review and meta-analysis. 2015;444:1-11.

[11] O’ Keeffe M, Purtill H, Kennedy N, et al. Comparative Effectiveness of Conservative Interventions for Nonspecific Chronic Spinal Pain: Physical, Behavioral/Psychologically Informed, or Combined? A Systematic Review and Meta-Analysis. J. Pain. 2016;17:755774.

[12] Eccleston C, Morley SJ, Williams AC d. C. Psychological approaches to chronic pain management: evidence and challenges. Br. J. Anaesth. 2013;111:59-63

[13] Wicksell RK, Olsson GL, Hayes SC. Psychological flexibility as a mediator of improvement in Acceptance and Commitment Therapy for patients with chronic pain following whiplash. Eur. J. Pain. 2010;14:1059.e1-1059.e11.

[14] Liberati A, Altman DG, Tetzlaff J, et al. The PRISMA statement for reporting systematic reviews and meta-analyses of studies that evaluate health care interventions: 
Explanation and elaboration. Ann. Intern. Med. 2009 [cited March 2016]. DOI: 10.1371/journal.pmed.1000100

[15] Higgins JPT, Altman DG, Gotzsche PC, et al. The Cochrane Collaboration's tool for assessing risk of bias in randomised trials. BMJ. 2011 [cited March 2016]. DOI: 10.1136/bmj.d5928

[16] Scottish Intercollegiate Guidelines Network. Critical appraisal notes and checklists [Internet] [cited April 2018]. Available from: http://www.sign.ac.uk/checklists-andnotes.html

[17] Khan M, Akhter S, Soomro RR, et al. The effectiveness of Cognitive Behavioral Therapy (CBT) with general exercises versus general exercises alone in the management of chronic low back pain. Pak. J. Pharm. Sci. 2014;27:1113-1116.

[18] Ludvigsson ML, Peterson G, O'Leary S, et al. The effect of neck-specific exercise with, or without a behavioral approach, on pain, disability, and self-efficacy in chronic whiplash-associated disorders: a randomised controlled trial. Clin. J. Pain. 2015;31:294-303.

[19] Ludvigsson ML, Peterson G, Dedering Å, et al. One- and two-year follow-up of a randomized trial of neck specific exercise with or without a behavioural approach compared with prescription of physical activity in chronic whiplash disorder. J Rehabil Med.

2016;48:56-64.

[20] Monticone M, Ambrosini E, Rocca B, et al. Group-based multimodal exercises integrated with cognitive-behavioural therapy improve disability, pain and quality of life of subjects with chronic neck pain : a randomized controlled trial with one-year follow-up. Clin Rehab. 2017;742-752.

[21] Monticone M, Ambrosini E, Rocca B, et al. A multidisciplinary rehabilitation programme improves disability, kinesiophobia and walking ability in subjects with chronic low back pain: results of a randomised controlled pilot study. Eur. Spine J. 2014;23:21052113.

[22] Monticone M, Ferrante S, Rocca B, et al. Effect of a long-lasting multidisciplinary program on disability and fear-avoidance behaviors in patients with chronic low back pain: results of a randomized controlled trial. Clin J Pain. 2013;29:929-938.

[23] Monticone M, Baiardi P, Vanti C, et al. Chronic neck pain and treatment of cognitive and behavioural factors: Results of a randomised controlled clinical trial. Eur. Spine J.

2012;21:1558-1566.

[24] Smeets RJEM, Beelen S, Goossens MEJB, et al. Treatment expectancy and credibility are associated with the outcome of both physical and cognitive-behavioral treatment in chronic low back pain. Clin. J. Pain. 2008;24:305-315.

[25] Smeets RJEM, Vlaeyen JWS, Hidding A, et al. Chronic low back pain: Physical training, graded activity with problem solving training, or both? The one-year post-treatment results of a randomized controlled trial. Pain. 2008;134:263-276.

[26] Smeets RJEM, Vlaeyen JWS, Hidding A, et al. Active rehabilitation for chronic low back pain: Cognitive-behavioral, physical, or both? First direct post-treatment results from a 
randomized controlled trial [ISRCTN22714229]. BMC Musculoskelet. Disord. 2006 [cited March 2016]. DOI: 10.1186/1471-2474-7-5

[27] Smeets RJEM, Vlaeyen JWS, Kester ADM, et al. Reduction of Pain Catastrophizing Mediates the Outcome of Both Physical and Cognitive-Behavioral Treatment in Chronic Low Back Pain. J. Pain. 2006;7:261-271.

[28] Söderlund A, Lindberg P. An integrated physiotherapy/cognitive-behavioural approach to the analysis and treatment of chronic whiplash associated disorders, WAD. Disabil. Rehabil. 2001;23:436-447.

[29] Söderlund A, Lindberg P. Cognitive behavioural components in physiotherapy management of chronic Whiplash Associated Disorder (WAD) - A randomised group study. G. Ital. Med. Lav. Ergon. 2007;29:A5-A11.

[30] The National Institute for Health and Care Excellence. Low back pain and sciatica in over 16s: assessment and management [Internet]. 2016. Available from: https://www.nice.org.uk/guidance/ng59.

[31] Arain M, Campbell MJ, Cooper CL, et al. What is a pilot or feasibility study? A review of current practice and editorial policy. BMC Med Res Methodol. 2010 [cited March 2016]. DOI: $10.1186 / 1471-2288-10-67$

[32] Keogh A, Tully MA, Matthews J, et al. A review of behaviour change theories and techniques used in group based self-management programmes for chronic low back pain and arthritis. Man. Ther. 2015;20:727-735.

[33] Alexanders J, Anderson A, Henderson S. Musculoskeletal physiotherapists' use of psychological interventions: a systematic review of therapists' perceptions and practice. Physiotherapy. 2014;101:95-102.

[34] Synnott A, Keeffe MO, Bunzli S, et al. Physiotherapists may stigmatise or feel unprepared to treat people with low back pain and psychosocial factors that influence recovery : a systematic review. J. Physiother. 2015;61:68-76.

[35] Toomey E, Currie-Murphy L, Matthews J, et al. The effectiveness of physiotherapistdelivered group education and exercise interventions to promote self-management for people with osteoarthritis and low back pain: A rapid review Part 1. Man. Ther. 2015;20:265-286.

[36] Toomey E, Currie-Murphy L, Matthews J, et al. Implementation fidelity of physiotherapist-delivered group education and exercise interventions to promote selfmanagement in people with osteoarthritis and chronic low back pain: A rapid review Part II. Man. Ther. 2015;20:287-294.

[37] Williams ACDC, Eccleston C, Morley S. Psychological therapies for the management of chronic pain ( excluding headache ) in adults ( Review ). Cochrane Review. 11 (2013). 


\section{Figure 1 Search Strategy}

"chronic pain" OR "long term pain" or "persistent pain" OR "arthritis pain"

AND

physiotherap* OR "physical therap*"

AND

psycholo* OR "cognitive behavioural therap*” OR "psychosocial approach" OR

"motivational interviewing" OR "acceptance and commitment therapy" 


\section{Figure 2 Flow Diagram of the Review Process}

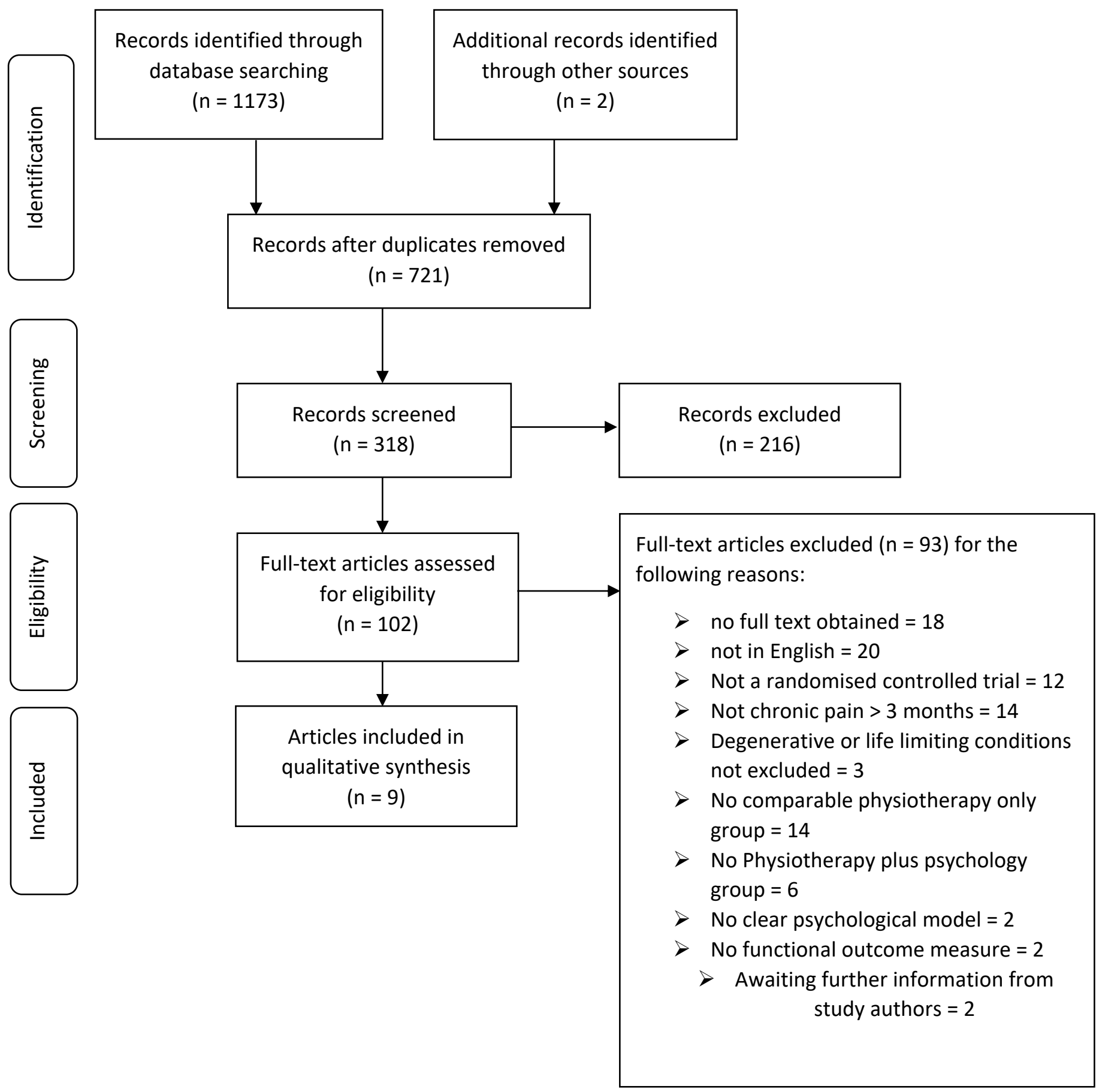


Table 1 Description of Studies

\begin{tabular}{|c|c|c|c|c|c|c|c|c|}
\hline Study & $\begin{array}{l}\text { Condition } \\
\text { and } \\
\text { physical } \\
\text { functioning } \\
\text { outcome } \\
\text { measure }\end{array}$ & Recruitment & $\begin{array}{l}\text { Total } \\
\text { entered } \\
\text { into } \\
\text { study (\% } \\
\text { female) }\end{array}$ & $\begin{array}{l}\text { Age range } \\
(\text { mean } \pm \text { SD) } \\
\text { years }\end{array}$ & $\begin{array}{l}\text { Physiotherapy } \\
\text { intervention }\end{array}$ & $\begin{array}{l}\text { Physiotherapy plus } \\
\text { psychological } \\
\text { intervention }\end{array}$ & Withdrawals & $\begin{array}{l}\text { Adverse } \\
\text { events }\end{array}$ \\
\hline $\begin{array}{l}\text { Khan et al } \\
{[17]}\end{array}$ & $\begin{array}{l}\text { NSLBP 3- } \\
24 \text { months } \\
\text { RMDQ }\end{array}$ & $\begin{array}{l}\text { Via two clinics } \\
\text { in Pakistan }\end{array}$ & $\begin{array}{l}\mathrm{N}=54 \\
(54 \%)\end{array}$ & $\begin{array}{l}29-50 \\
(39.61 \pm \\
5.3)\end{array}$ & $\begin{array}{l}\text { General } \\
\text { exercise: range } \\
\text { of movement } \\
\text { and aerobic } \\
\text { training. } 3 \\
\text { supervised } \\
\text { sessions/week } \\
\text { plus } 2 \text { xdaily } \\
\text { home exercise } \\
\text { on } 5 \text { days/week } \\
\text { for } 12 \text { weeks. }\end{array}$ & $\begin{array}{l}\text { General exercise as } \\
\text { physiotherapy only } \\
\text { group plus CBT: } \\
\text { operant behavioural } \\
\text { graded activity and } \\
\text { problem-solving } \\
\text { training. }\end{array}$ & None & $\begin{array}{l}\text { Not } \\
\text { reported }\end{array}$ \\
\hline $\begin{array}{l}\text { Ludvigsson } \\
\text { et al } \\
{[18-19]}\end{array}$ & $\begin{array}{l}\text { Chronic } \\
\text { whiplash } \\
\text { disorder }\end{array}$ & $\begin{array}{l}\text { Patients } \\
\text { identified from } \\
\text { healthcare } \\
\text { registers in } 6 \\
\text { Swedish } \\
\text { counties }\end{array}$ & $\mathrm{N}=216$ & $\begin{array}{l}\text { PTcb }(n=71) \\
40 \pm 11.6 \\
\text { PT }(n=76) \\
38 \pm 11.3\end{array}$ & $\begin{array}{l}\text { Supervised } \\
\text { exercise and } \\
\text { basic } \\
\text { information. } 2 \\
\text { sessions weekly } \\
\text { plus home } \\
\text { exercises. } \\
\text { Unrestricted } \\
\text { isometric } \\
\text { exercise }\end{array}$ & $\begin{array}{l}\text { As physiotherapy } \\
\text { only but progressed } \\
\text { more slowly with } \\
\text { patients encouraged } \\
\text { to be responsible for } \\
\text { progression, plus } \\
\text { pain education, } \\
\text { activities aimed at } \\
\text { pain management } \\
\text { and problem }\end{array}$ & None & $\begin{array}{l}\text { Not } \\
\text { reported }\end{array}$ \\
\hline
\end{tabular}




\begin{tabular}{|c|c|c|c|c|c|c|c|c|}
\hline & & & & & $\begin{array}{l}\text { progressing to } \\
\text { low isometric } \\
\text { resistance and } \\
\text { resistance } \\
\text { training. }\end{array}$ & $\begin{array}{l}\text { solving, relaxation } \\
\text { and home practice. }\end{array}$ & & \\
\hline $\begin{array}{l}\text { Monticone } \\
\text { et al [20] }\end{array}$ & $\begin{array}{l}\text { Chronic } \\
\text { neck pain } \\
>3 \text { months } \\
\text { NDI }\end{array}$ & $\begin{array}{l}\text { Via } 1 \text { hospital } \\
\text { outpatient clinic }\end{array}$ & $\begin{array}{l}\mathrm{N}=170 \\
(71.2 \%)\end{array}$ & $\begin{array}{l}\text { PTcb }(n=85) \\
53.8 \pm 13.3 \\
\text { PT }(n=85) \\
52.0 \pm 12.1\end{array}$ & $\begin{array}{l}\text { Exercises for } \\
\text { strengthening, } \\
\text { regional } \\
\text { stretching and } \\
\text { spinal } \\
\text { mobilization. } \\
\text { Ergonomic } \\
\text { advice booklet. } \\
\text { One session per } \\
\text { week for } 10 \\
\text { weeks in groups } \\
\text { of } 5 \text { patients. }\end{array}$ & $\begin{array}{l}\text { Exercise introduced } \\
\text { by means of graded } \\
\text { exposure for cervical } \\
\text { mobility, postural } \\
\text { control, stretching } \\
\text { and strengthening } \\
\text { plus group-based } \\
\text { CBT. } 1 \text { hour per } \\
\text { week of exercise and } \\
\text { CBT for } 10 \text { weeks. }\end{array}$ & $\begin{array}{l}\text { PT only } n=6 \\
\text { did not start } \\
\text { intervention, } \\
n=4 \text { lack of } \\
\text { time, } n=1 \\
\text { increased } \\
\text { pain, } n=3 \\
\text { other disease, } \\
\text { unknown } \\
n=4\end{array}$ & $\begin{array}{l}\text { Transient } \\
\text { pain } \\
\text { worsening } \\
\text { (combined } \\
\text { group } n=8, \\
\text { physio } \\
\text { only } n=12 \text { ) } \\
\text { Mood } \\
\text { disorders } \\
\text { (combined } \\
\text { group } n=5, \\
\text { physio } \\
\text { only } n=8 \text { ) }\end{array}$ \\
\hline $\begin{array}{l}\text { Monticone } \\
\text { et al [21] }\end{array}$ & $\begin{array}{l}\text { NSLBP > } \\
3 \text { months } \\
\text { duration } \\
\text { ODQ }\end{array}$ & $\begin{array}{l}\text { Via outpatient } \\
\text { department }\end{array}$ & $\begin{array}{l}N=20 \\
(55 \%)\end{array}$ & $(57.75)$ & $\begin{array}{l}\text { Passive spinal } \\
\text { mobilisation, } \\
\text { stretching, } \\
\text { muscle } \\
\text { strengthening } \\
\text { and postural } \\
\text { control } \\
\text { Individual } 60 \\
\text { minute motor } \\
\text { training } \\
\text { sessions } 2 \mathrm{x} /\end{array}$ & $\begin{array}{l}\text { CBT and spinal } \\
\text { stabilisation } \\
\text { exercises in addition } \\
\text { to physiotherapy } \\
\text { only treatment } \\
\text { programme. } \\
\text { Clinical } \\
\text { psychologist } \\
\text { delivered CBT: } \\
\text { modification of fear } \\
\text { of movement }\end{array}$ & None & $\begin{array}{l}\text { Not } \\
\text { reported }\end{array}$ \\
\hline
\end{tabular}




\begin{tabular}{|c|c|c|c|c|c|c|c|c|}
\hline & & & & & $\begin{array}{l}\text { week for } 8 \\
\text { weeks }\end{array}$ & $\begin{array}{l}\text { beliefs, } \\
\text { catastrophizing and } \\
\text { negative feelings } \\
\text { and ensuring gradual } \\
\text { reactions to illness } \\
\text { behaviours. } \\
\text { Cognitive } \\
\text { reconditioning and } \\
\text { graded exposure. } \\
\text { Additional } 60 \\
\text { minutes once/ week } \\
\text { for } 8 \text { weeks. }\end{array}$ & & \\
\hline $\begin{array}{l}\text { Monticone } \\
\text { et al [22] }\end{array}$ & $\begin{array}{l}\text { NSLBP > } \\
3 \text { months } \\
\text { duration } \\
\text { RMDQ }\end{array}$ & $\begin{array}{l}\text { Via research } \\
\text { hospital } \\
\text { outpatient } \\
\text { department }\end{array}$ & $\begin{array}{l}\mathrm{N}=90 \\
(57.78 \%)\end{array}$ & (49.34) & $\begin{array}{l}\text { Multimodal } \\
\text { motor } \\
\text { programme: } \\
\text { active and } \\
\text { passive spinal } \\
\text { mobilisations, } \\
\text { exercises aimed } \\
\text { at stretching } \\
\text { and } \\
\text { strengthening } \\
\text { muscles and } \\
\text { improving } \\
\text { postural control } \\
\text { Individual } \\
\text { programme } \\
\text { followed by the } \\
\text { patient. } 10 \times 60 \\
\text { minute sessions }\end{array}$ & $\begin{array}{l}\text { Physiotherapy } \\
\text { intervention plus } \\
\text { CBT: modification } \\
\text { of fear of movement } \\
\text { beliefs, catastrophic } \\
\text { thinking and } \\
\text { negative feelings } \\
\text { and ensuring gradual } \\
\text { reactions to illness } \\
\text { behaviours, graded } \\
\text { exposure and } \\
\text { acquisition and } \\
\text { development of } \\
\text { neglected coping } \\
\text { strategies through } \\
\text { communication, } \\
\text { motivation and goal } \\
\text { sharing. }\end{array}$ & None & $\begin{array}{l}\text { Not } \\
\text { reported }\end{array}$ \\
\hline
\end{tabular}




\begin{tabular}{|c|c|c|c|c|c|c|c|c|}
\hline & & & & & $\begin{array}{l}2 \mathrm{x} \text { a week for } 5 \\
\text { weeks then } 2 \mathrm{x} \\
\text { weekly } 60 \\
\text { minute home } \\
\text { exercise } \\
\text { sessions for } 1 \\
\text { year with } \\
\text { telephone } \\
\text { reminders }\end{array}$ & $\begin{array}{l}60 \text { minute individual } \\
\text { sessions once/ week } \\
\text { for } 5 \text { weeks then } 1 \\
\text { hour once/ month } \\
\text { for } 1 \text { year }\end{array}$ & & \\
\hline $\begin{array}{l}\text { Monticone } \\
\text { et al [23] }\end{array}$ & $\begin{array}{l}\text { Non- } \\
\text { specific } \\
\text { neck pain } \\
>3 \text { months } \\
\text { duration } \\
\text { NPDS }\end{array}$ & $\begin{array}{l}\text { Outpatient } \\
\text { department }\end{array}$ & $\begin{array}{l}N=80 \\
(75 \%)\end{array}$ & $\begin{array}{l}\text { PTcb }(n=40) \\
54.97 \pm 13.83 \\
\\
\text { PT } 44.20 \pm \\
11.44 \\
(p<0.001)\end{array}$ & $\begin{array}{l}\text { Manual } \\
\text { Therapy and } \\
\text { exercise } \\
\text { including active } \\
\text { and passive } \\
\text { neck } \\
\text { mobilisation, } \\
\text { postural and } \\
\text { motor control } \\
\text { work for deep } \\
\text { muscles of the } \\
\text { neck. } \\
\text { Up to } 12 \\
\text { sessions, } 45-50 \\
\text { minutes each, } \\
1-2 x \text { a week. } \\
\text { Discharge when } \\
\text { pain free for } 15 \\
\text { days minimum } \\
\text { and Cx spine }\end{array}$ & $\begin{array}{l}\text { Physiotherapy } \\
\text { programme as for } \\
\text { physiotherapy only } \\
\text { group psychology } \\
\text { consisted of graded } \\
\text { activities, pain } \\
\text { education, } \\
\text { modification of fear- } \\
\text { avoidance and } \\
\text { catastrophisation, } \\
\text { modification of pain } \\
\text { experience, } \\
\text { inappropriate } \\
\text { thinking and pain } \\
\text { behaviours. }\end{array}$ & $\begin{array}{l}5 \\
\text { withdrawals } \\
\text { reported in } \\
\text { the PT group. } \\
\text { Data } \\
\text { included in } \\
\text { the ITT } \\
\text { analysis }\end{array}$ & $\begin{array}{l}\text { Not } \\
\text { reported }\end{array}$ \\
\hline
\end{tabular}




\begin{tabular}{|c|c|c|c|c|c|c|c|c|}
\hline & & & & & $\begin{array}{l}\text { function } \\
\text { normal. }\end{array}$ & $\begin{array}{l}\text { free for } 15 \text { days } \\
\text { minimum and } \mathrm{Cx} \\
\text { spine function } \\
\text { normal. }\end{array}$ & & \\
\hline $\begin{array}{l}\text { Smeets et } \\
\text { al [24-27] }\end{array}$ & $\begin{array}{l}\text { NSLBP } \\
>3 \text { months } \\
\text { Functional } \\
\text { limitation } \\
\text { (RMDQ } \\
>3 \text { ) } \\
\text { RMDQ }\end{array}$ & $\begin{array}{l}\text { Via } 3 \text { outpatient } \\
\text { rehabilitation } \\
\text { clinics }\end{array}$ & $\begin{array}{l}N=227 \\
(45.9 \%)\end{array}$ & $\begin{array}{l}(41.91 \pm \\
9.65)\end{array}$ & $\begin{array}{l}\text { APT including } \\
\text { CV and } \\
\text { dynamic } \\
\text { strengthening } \\
1.75 \text { hours } 3 \mathrm{x} / \\
\text { week for } 10 \\
\text { weeks. }\end{array}$ & $\begin{array}{l}\text { APT, as } \\
\text { physiotherapy group } \\
\text { plus CBT: operant } \\
\text { behavioural graded } \\
\text { activity training. } \\
11.5 \text { hours treatment } \\
\text { primarily } \\
\text { individually and } \\
\text { problem solving } 10 \\
\text { x } 1.5 \text { hour sessions } \\
\text { with clinical } \\
\text { psychologist in } \\
\text { groups of up to } 4 .\end{array}$ & $\begin{array}{l}6 \\
\text { withdrawals } \\
\text { during } \\
\text { treatment, } \\
\text { data were } \\
\text { included in } \\
\text { ITT analysis. }\end{array}$ & $\begin{array}{l}6 \text { patients. } \\
3 \text { /group. } \\
1 \mathrm{x} \\
\text { herniated } \\
\text { disc } \\
\text { requiring } \\
\text { surgery, } 1 \mathrm{x} \\
\text { knee } \\
\text { complaint } \\
\text { and 1x } \\
\text { vascular } \\
\text { problems } \\
\text { requiring } \\
\text { surgery. }\end{array}$ \\
\hline $\begin{array}{l}\text { Söderlund } \\
\& \\
\text { Lindberg } \\
{[28-29]}\end{array}$ & $\begin{array}{l}\text { Whiplash } \\
\text { injury with } \\
\text { continuous } \\
\text { symptoms } \\
\text { at }>3 \\
\text { months } \\
\text { post injury. }\end{array}$ & $\begin{array}{l}\text { Via an } \\
\text { orthopaedic } \\
\text { clinic }\end{array}$ & $\begin{array}{l}N=33 \\
(57.58 \%)\end{array}$ & (40.69) & $\begin{array}{l}\text { Exercises for } \\
\text { neck } \\
\text { stabilisation, } \\
\text { neck and } \\
\text { shoulder } \\
\text { mobility, } \\
\text { posture and arm } \\
\text { strength. } \\
\text { Relaxation, } \\
\text { TENS, } \\
\text { acupuncture } \\
\text { and heat. }\end{array}$ & $\begin{array}{l}\text { Basic skills included } \\
\text { relaxation training } \\
\text { and postural re- } \\
\text { education, exercises } \\
\text { for neck mobility } \\
\text { and muscular } \\
\text { coordination and } \\
\text { endurance and re- } \\
\text { education of normal } \\
\text { humeroscapular } \\
\text { rhythm }\end{array}$ & $\begin{array}{l}\text { One patient } \\
\text { in combined } \\
\text { intervention } \\
\text { did not } \\
\text { comply with } \\
\text { treatment and } \\
\text { was excluded } \\
\text { from the } \\
\text { analysis }\end{array}$ & $\begin{array}{l}\text { Not } \\
\text { reported }\end{array}$ \\
\hline
\end{tabular}




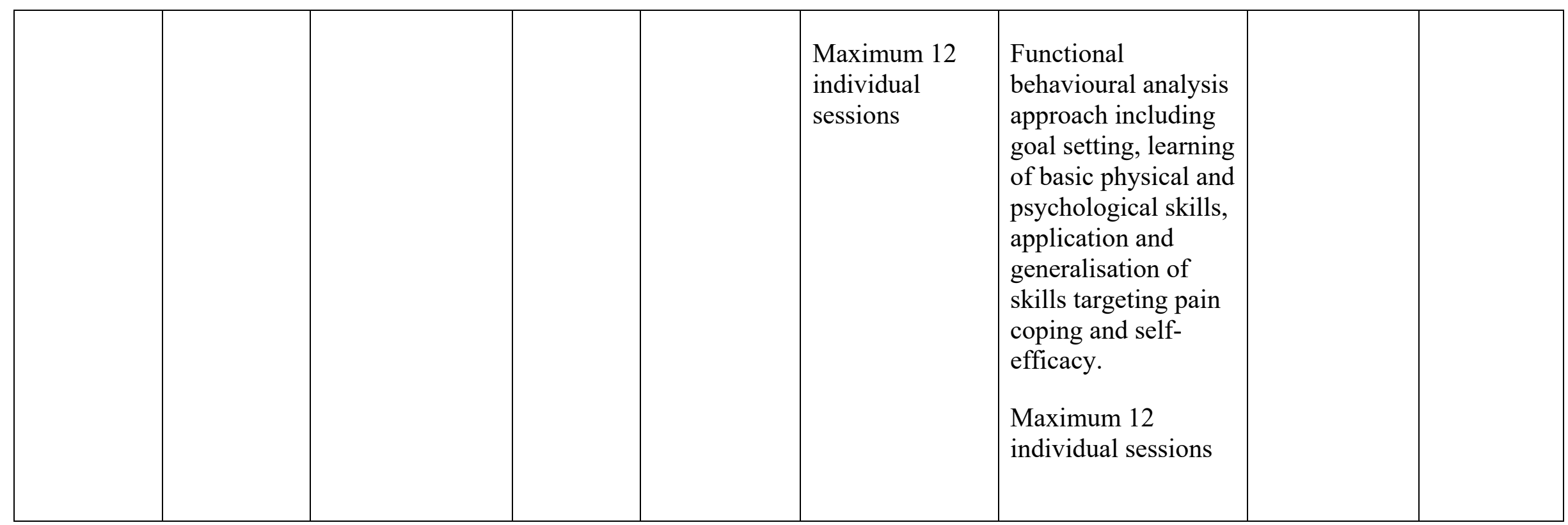

$\mathrm{APT}=$ active physical treatment $\mathrm{CBT}=\mathrm{Cognitive}$ Behavioural Therapy; $\mathrm{CT}=$ combined treatment $\mathrm{CV}=$ cardiovascular; $\mathrm{Cx}=$ cervical ITT $=$ intention to treat; NDI=Neck Disability Index; NPDS = Neck Pain and Disability Score; NSLBP= Non-specific low back pain; ODQ=Oswestry Disability Questionnaire; PDI=Pain Disability Index; PT = physiotherapy; RMDQ = Roland Morris Disability Questionnaire; TENS =

Transcutaneous Electrical Nerve Stimulation. 
Table 2 Cochrane Risk of Bias Ratings

\begin{tabular}{|c|c|c|c|c|c|c|c|}
\hline & $\begin{array}{l}\text { Random } \\
\text { sequence } \\
\text { allocation }\end{array}$ & $\begin{array}{l}\text { Allocation } \\
\text { concealme } \\
\text { nt }\end{array}$ & $\begin{array}{l}\text { Blinding } \\
\text { of } \\
\text { participant } \\
\text { s and } \\
\text { personnel }\end{array}$ & $\begin{array}{l}\text { Blinding } \\
\text { of outcome } \\
\text { assessment }\end{array}$ & $\begin{array}{l}\text { Incomplete } \\
\text { outcome } \\
\text { data }\end{array}$ & $\begin{array}{l}\text { Selective } \\
\text { reporting }\end{array}$ & Other bias \\
\hline $\begin{array}{l}\text { Khan } 2014 \\
\text { [17] }\end{array}$ & ? & ? & - & ? & + & + & $?$ \\
\hline $\begin{array}{l}\text { Ludvigsson } \\
2015 \text { [18] }\end{array}$ & + & + & - & + & + & + & $?$ \\
\hline $\begin{array}{l}\text { Monticone } \\
2017[20]\end{array}$ & + & + & - & + & + & + & + \\
\hline $\begin{array}{l}\text { Monticone } \\
2014 \text { [21] }\end{array}$ & + & + & - & + & + & + & $?$ \\
\hline $\begin{array}{l}\text { Monticone } \\
2013 \text { [22] }\end{array}$ & + & + & - & + & + & + & $?$ \\
\hline $\begin{array}{l}\text { Monticone } \\
2012 \text { [23] }\end{array}$ & + & + & - & + & + & + & ? \\
\hline $\begin{array}{l}\text { Smeets } \\
2006[26]\end{array}$ & + & + & - & $?$ & + & + & $?$ \\
\hline \multirow[t]{4}{*}{$\begin{array}{l}\text { Soderlund } \\
\text { \& } \\
\text { Lindberg } \\
2001[28] \\
\end{array}$} & + & $?$ & - & - & - & - & - \\
\hline & - & \multicolumn{2}{|c|}{ High risk of bias } & & & & \\
\hline & + & \multicolumn{2}{|c|}{ Low risk of bias } & & & & \\
\hline & $?$ & \multicolumn{2}{|c|}{$\begin{array}{l}\text { Risk of bias cannot be } \\
\text { ascertained }\end{array}$} & & & & \\
\hline
\end{tabular}


Table 3 Summary of Study Results

\begin{tabular}{|c|c|c|}
\hline Study & Physical functioning & Quality of life \\
\hline $\begin{array}{l}\text { Khan (2014) } \\
{[17]}\end{array}$ & $\begin{array}{l}\text { RMDQ: statistically significant } \\
\text { difference**** in both groups over } \\
\text { time. No statistically significant } \\
\text { difference between groups. }\end{array}$ & Not measured \\
\hline $\begin{array}{l}\text { Ludvigsson } \\
(2015)[18]\end{array}$ & $\begin{array}{l}\text { NDI: statistically significant } \\
\text { difference in both groups over time } \\
\text { (pt only**, combined } \\
\text { treatment***). No statistically } \\
\text { significant difference between } \\
\text { groups. }\end{array}$ & Not measured \\
\hline $\begin{array}{l}\text { Monticone } \\
(2017)[20]\end{array}$ & $\begin{array}{l}\text { NDI: statistically significant } \\
\text { difference within groups over } \\
\text { time*** and between groups } * * * \text {. }\end{array}$ & $\begin{array}{l}\text { SF36: statistically significant } \\
\text { difference within groups over } \\
\text { time*** and between groups } * * * \text {. }\end{array}$ \\
\hline $\begin{array}{l}\text { Monticone } \\
\text { 2014) [21] }\end{array}$ & $\begin{array}{l}\text { Oswestry Disability Questionnaire: } \\
\text { improved by about } 25 \% \text { in the } \\
\text { physiotherapy only group and } 61 \% \\
\text { in the physiotherapy plus } \\
\text { psychology group, indicating } \\
\text { significant effects of time***, } \\
\text { group* and time-by-group*** } \\
\text { interaction in favour of the } \\
\text { combined treatment group. }\end{array}$ & $\begin{array}{l}\text { SF36: improved across most sub- } \\
\text { scales indicating statistically } \\
\text { significant effects of time**, } \\
\text { group* and time-by-group } \\
\text { interaction* in favour of the } \\
\text { combined treatment group. The } \\
\text { items which did not show } \\
\text { statistically significant effects of } \\
\text { time-by-group were physical role } \\
\text { and bodily pain. }\end{array}$ \\
\hline $\begin{array}{l}\text { Monticone } \\
(2013)[22]\end{array}$ & $\begin{array}{l}\text { RMDQ: progressively reduced } \\
\text { between pre and } 2 \text { year follow-up }\end{array}$ & $\begin{array}{l}\text { SF36: decreased statistically } \\
\text { significantly between pre-treatment }\end{array}$ \\
\hline
\end{tabular}




\begin{tabular}{|c|c|c|}
\hline & $\begin{array}{l}\text { in the combined treatment group } \\
\text { with repeated measure linear mixed } \\
\text { model showing significant main } \\
\text { effects for group and time in favour } \\
\text { of the combined treatment } \\
\text { group*** }\end{array}$ & $\begin{array}{l}\text { and } 1 \text { year follow-up showing } \\
\text { statistically significant effects of } \\
\text { time, group and time-by-group } \\
\text { interaction*** in favour of the } \\
\text { combined treatment group. }\end{array}$ \\
\hline $\begin{array}{l}\text { Monticone } \\
(2012) \text { [23] }\end{array}$ & $\begin{array}{l}\text { NPDS: both groups showed } \\
\text { improvement but no statistical } \\
\text { difference between groups }\end{array}$ & $\begin{array}{l}\text { SF36: both groups showed } \\
\text { improvement but no statistical } \\
\text { difference between groups }\end{array}$ \\
\hline $\begin{array}{l}\text { Smeets (2006) } \\
{[26]}\end{array}$ & $\begin{array}{l}\text { RMDQ: statistically significant } \\
\text { difference** in both groups over } \\
\text { time. No statistically significant } \\
\text { difference between groups }\end{array}$ & Not measured \\
\hline $\begin{array}{l}\text { Soderlund and } \\
\text { Lindberg [28] }\end{array}$ & $\begin{array}{l}\text { PDI: no significant difference over } \\
\text { time in disability for either group at } \\
\text { post treatment, } 3 \text { or } 6 \text { month } \\
\text { follow-up. } \\
\text { Combined group analysis showed a } \\
\text { statistically significant } \\
\text { improvement** in disability at } 6 \\
\text { months post treatment }\end{array}$ & Not measured \\
\hline
\end{tabular}

${ }^{*} \mathrm{p}<0.05 ; * * \mathrm{p}<0.01 ; * * * \mathrm{p}<0.001 ; * * * * \mathrm{p}=0.000 ;$ NDI=Neck Disability Index; NPDS = Neck

Pain and Disability Score; PDI = Pain Disability Index; RMDQ = Roland Morris Disability

Questionnaire; SF36 = Short-Form Health Survey Questionnaire; WL=waiting list 
Figure 3 Effects of Physiotherapy plus psychology intervention compared with physiotherapy alone on physical functioning

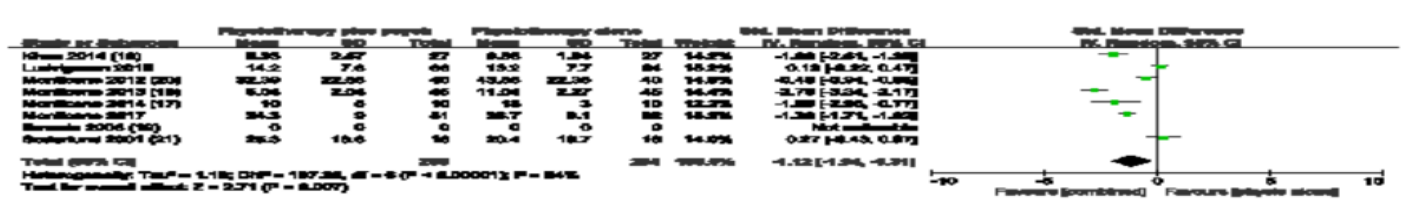

